\title{
High-temperature melting of refractory lower crust in the inner zone of the Emeishan large igneous province: constraints from the Permian A-type granites from the Panxi region
}

\author{
Z.Z. ZHANG, J.F. QIN *, S.C. LAI, X.P. LONG, Y.J. \\ JU, X.Y. WANG, Y. ZHU, F.Y.ZHANG
}

State Key Laboratory of Continental Dynamics,Departmentof Geology, Northwest University, Xi'an, 710069, China

E-mail: Zezhong Zhang, zhangzezhong@stumail.nwu.edu.cn; Corresponding author: Jiangfeng Qin, qinjf@nwu.edu.cn

The felsic magma from inner zone of the Permian Emeishan Large Igneous Province, southwest China, preserves unique information of crustal response to the Emeishan mantle plume activity. We present detailed petrology, mineral chemistry, chronology, major and trace element geochemistry and zircon $\mathrm{Hf}$ isotopes to addresses the petrogenesis of the contemporaneous ( 259Ma) Baima granite and ferrosyenites from Panxi region. The Baima granite have high $\mathrm{SiO}_{2}$ (70.58 to 74.26 wt.\%), $\mathrm{Al}_{2} \mathrm{O}_{3}$ (12.49 to 14.21 wt.\%) contents and enriched zircon Lu-Hf isotopic composition $(\varepsilon \mathrm{Hf}(\mathrm{t})=-8.1$ to -0.6$)$. The diagenesis of biotite from the granite was under $\sim 0.6 \mathrm{kbar}$ and $\sim 680^{\circ} \mathrm{C}$ condition, corresponding to shallow solidification depth of $\sim 2 \mathrm{~km}$. Combined with the Rcrust modeling, the Baima granite could be derived from low degree partial melting of the ancient dioritic gneisses middle-lower crust in the Yangtze Craton. The Baima ferrosyenites mainly consists of alkali feldspar, fayalite and hedenbergite and chararcterized by high $\mathrm{Fe} /(\mathrm{Fe}+\mathrm{Mg})$ and $\mathrm{K}_{2} \mathrm{O} / \mathrm{Na}_{2} \mathrm{O}$ ratios. Zircons from the ferrosyenite have variable $\varepsilon \mathrm{Hf}(\mathrm{t})$ values of +1.5 to +12.9 with TDM ages of 0.37 to $0.86 \mathrm{Ga}$, combined with the Neoproterozoic zircons occurred in the host rocks, indicating their source is primarily juvenile crust added during Emeishan volcanism, with incorporation of minor amounts of Neoproterozoic crust. The obviously whole-rock and mineral compositional variations of ferrosyenites indicate evolution of the primary magma are mainly controlled by fractional crystallization process. We propose that the mantle plume provides the high-temperature and triggered the melting of refractory ferrodioritic juvenile lower crust in a relatively anhydrous condition, producing primary ferrosyenitic magma. Then this ferrosyenitic magma ascend to the middle-lower crust levels with the evolution process and caused partial melting of the ancient dioritic gneisses to form the Baima granite. 